\title{
MORPHOLOGICAL AND MORPHOMETRIC STUDY OF FORAMEN
} SPINOSUM

\section{Shaik Hussain Saheb ${ }^{1}$, Khaleel N *2, Pavan P Havaldar ${ }^{3}$, Shruthi B.N 4}

${ }^{* 1}$ Assistant professor of Anatomy, JJM M edical College, davanagere, Karnataka, India.

${ }^{2}$ Assistant Professor of Anatomy, St. John's M edical College and Hospital, Bangalore, Karnataka, India.

${ }^{3}$ Associate Professor Department of Anatomy, Gadag Institute of M edical Sciences, Gadag, India.

${ }^{4}$ Associate Professor, Department of Anatomy, Raja Rajeswari Medical College \& Hospital, Bengaluru, India.

\section{ABSTRACT}

\begin{abstract}
Back ground: The foramen spinosum is one of important foramina located in the base of the skull on the greater wing of sphenoid bone situated posteriorlaterally to the foramen ovale, therefore it could be identified both from the exterior and interior of the skull base, externally the foramen spinosum pierces the spinous process of the sphenoid bone at its apex or medial aspect. Foramen spinosum transmits the passage of the middle meningeal artery, parietal trunk of the middle meningeal artery and posterior trunk of the middle meningeal vein to the middle cranial fossa.

Materials and M ethods: Total 300 skull were used for this study. The shape of foramen spinosum and diameter of it recorded with vernier calipers.

Results: Foramen spinosum found as round shape in $58 \%$, oval shape in $38 \%$ and irregular in $4 \%$. The maximum diameter of foramen spinosum was $2.77+0.97 \mathrm{~mm}$ and $2.03+0.56 \mathrm{~mm}$ was minimum in females, in males maximum diameter was $2.95+0.56 \mathrm{~mm}$ and $1.52+0.82 \mathrm{~mm}$ as minimum. The knowledge of foramen spinosum is great helpful for neurosurgeons.

Conclusion: The round shape wasfound in more number of skulls and veryfew wereirregular shape. The knowledge of foramen spinosum help to cranial surgeons as it is transmitting middle meningeal artery.

KEY WORLD: Foramen spinosum, Middle mengeal artery, dry skull, sphenoid bone.
\end{abstract}

Address for Correspondence: Dr. Khaleel N, Assistant Professor of Anatomy, St. John's M edical College and Hospital, Koramangala, Bangalore-560034, Karnataka, India.

E-Mail: drkhaleel2013@gmail.com

\begin{tabular}{|c|c|c|}
\hline \multicolumn{3}{|c|}{ Access this Article online } \\
\hline \multirow{2}{*}{$\begin{array}{l}\text { Quick Response code } \\
\text { Dol: } 10.16965 / \text { ijar.2017.389 }\end{array}$} & \multicolumn{2}{|c|}{$\begin{array}{l}\text { Web site: International Journal of Anatomy and Research } \\
\text { ISSN 2321-4287 } \\
\text { www.ijmhr.org/ijar.htm }\end{array}$} \\
\hline & $\begin{array}{l}\text { Received: } 03 \text { Aug } 2017 \\
\text { Peer Review: } 03 \text { Aug } 2017 \\
\text { Revised: None }\end{array}$ & $\begin{array}{l}\text { Accepted: } 05 \text { Sep } 2017 \\
\text { Published (O): } 01 \text { Oct } 2017 \\
\text { Published (P): } 01 \text { Oct } 2017\end{array}$ \\
\hline
\end{tabular}

\section{INTRODUCTION}

The greater wing of the sphenoid bone is marked by numerous foramina which transmit vital neural and vascular structures[1]. These foramina are characteristically situated along the medial aspect of the floor of the middle cranial fossa. $M$ any variants have been described in the anatomic and radiologic literature which is not only important to understand the complex regional neurovascular anatomy but also to distinguish the normal from the potentially abnormal structures [2,3]. One such foramen is the foramen spinosum which is located in close proximity posterolateral to foramen ovale and transmits the middle meningeal vessels, the meningeal branch of mandibular nerve and the nervous 
spinosus [1]. The transmission of these neurovascular structures allows for communication between the middle cranial and the infratemporal fossae[4,5].

It transmits middle meningeal artery, nervous spinosus and occasionally posterior trunk of middle meningeal sinus. Middle meningeal artery may arise from ophthalmic artery instead of maxillary artery and enter into cranial cavity through superior orbital fissure in which, FSmay be absent. Early division of middle meningeal artery before passing through FS may be the cause of duplication of foramen spinosum $[6,7,8]$. Foramen spinosum has been described as an important landmark for microsurgical procedure involving middle cranial fossa particularly when using middle meningeal artery as a donor graft for either internal carotid artery or posterior cerebral artery bypass surgery $[9,10]$.

Hence detailed anatomical knowledge including developmental aspect is really worthwhile as far as neurosurgery and radiology is concerned. As per development of sphenoid bone is concerned, it is derived from both intramembranous and intracartilaginous ossification centres. Out of eight post sphenoid ossification centres, first ossification centre appears for greater wing of sphenoid i.e. Alisphenoid at about 8 weak of intrauterine life by membranous ossification. Foramen spinosum is visualized earliest by eight month after birth and gradually becomes prominent latest by seven year. In this regard, postnatal changes of Foramen spinosum have been described by Lang et al[11]. Thus, developmental background of sphenoid bone may explain various asymmetries in shape, size including different bony outgrowth affecting the margin this foramen. Available literatures reveal that foramen spinosum can exhibit a wide range of variations. This study was conduct to establish a source of reliable data and thus minimizing hazards of modern diagnostic and therapeutic procedures involving middle cranial fossa. M orphometric studies helps in clinical practices of related surgeries[12].

\section{MATERIALS AND METHODS}

300 skulls dry adult human skulls constituted the material for the present study. The skulls were collected from the Department of Anatomy, JJM Medical College, Rajarajeswari medical College, Gadag govt medical college, Karnataka, India. Each was studied for the morphometric analysis of foramen spinosum and recorded. Maximum and minimum diameter was measured and recorded. The different shapes of foramen spinosum were also recorded and percentage of shapes were calculated. M easurements were expressed in mean $\_S D$.

\section{RESULTS}

Total 300 skulls were used for this study. The results were foramen spinosum found as round shape in $58 \%$, oval shape in $38 \%$ and irregular in $4 \%$. The maximum diameter of foramen spinosum was $2.77+0.97 \mathrm{~mm}$ and $2.03+0.56 \mathrm{~mm}$ was minimum in females, in males maximum was $2.95+0.56 \mathrm{~mm}$ and $1.52+0.82 \mathrm{~mm}$ as minimum.

Table 1: Shapes of Foramen Spinosum.

\begin{tabular}{|c|c|}
\hline Shape of foramen spino sum & Incidence \\
\hline Round shape & $58 \%$ \\
\hline Oval shape & $38 \%$ \\
\hline Irregular shape & $4 \%$ \\
\hline
\end{tabular}

Table 2: Sizes of Foramen Spinosum.

\begin{tabular}{|c|c|c|}
\hline Sex & $\begin{array}{c}\text { Maximum } \\
\text { diameter }\end{array}$ & $\begin{array}{c}\text { Minimum } \\
\text { diameter }\end{array}$ \\
\hline Female & $2.77+0.97 \mathrm{~mm}$ & $2.03+0.56 \mathrm{~mm}$ \\
\hline Male & $2.95+0.56 \mathrm{~mm}$ & $1.52+0.82 \mathrm{~mm}$ \\
\hline
\end{tabular}

Fig. 1: Showing base of skull with foramen spinosum.

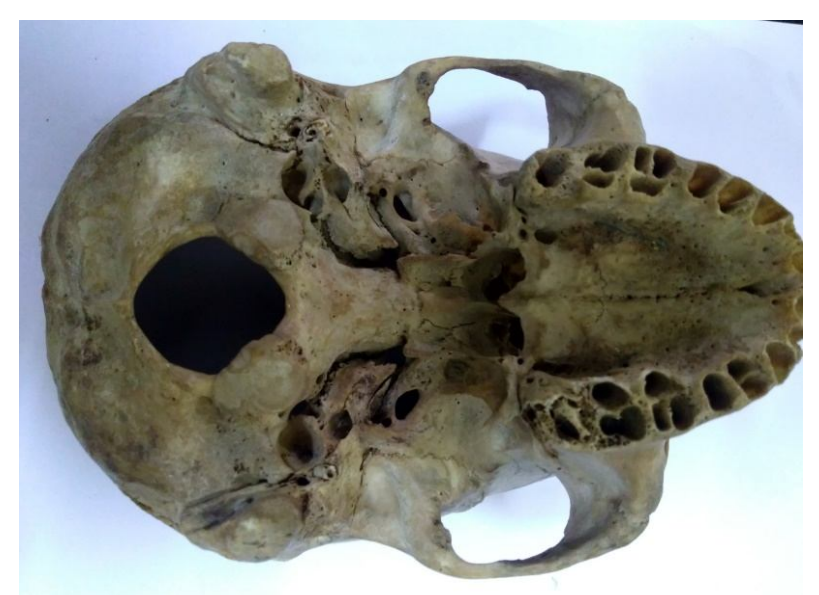

\section{DISCUSSION}

The Foramen Spinosum is one of the foramen that lies in the greater wing of Sphenoid, provides communication between middle cranial 
fossa and infratemporal fossa. It lies posterolateral to foramen ovale. It transmits middle meningeal artery, Nervus Spinosus and middle meningeal vein [13-15]. The Foramen spinosum contains a venous component, the middle meningeal vein which connects the cavernous sinus with the pterygoid venous plexus, this is an important factor for clinical evaluation of radiological images of the diseased region. In present study we have observed the foramen spinosum in $98.9 \%$ cases, this one in agreement with different authors who have been reported in their studies with the percentage of 99.6\%[16], 99.2\%[17], and 98.5\%[11]. Lindblom found that absence of foramen spinosum in $0.4 \%$ cases the reason would be the middle meningeal artery arose from the ophthalmic artery, in rare cases early division of the middle meningeal artery into an anterior and posterior division may result in the duplication of the foramen spinosum [16], our present study also observed that 1.1\% of skulls with absence of foramen spinosum. In Wood-Jones study found the foramen spinosum to be more or less incomplete in approximately $44 \%$ and in $16 \%$, the foramen in the right side was unclosed $84 \%$ were open[18].

According to Lang et al. the foramen spinosum was about $2.25 \mathrm{~mm}$ in the new born and $2.56 \mathrm{~mm}$ length in adults, the width of the foramen spinosum rangefrom 1.05 to about $2.1 \mathrm{~mm}$ in adults [11], these findings are in agreement with our present study. The findings of Osunwoke EA et al study results were slightly differs from present study, the results of there study were the maximal length of foramen spinosum was $4.0 \mathrm{~mm}$ and minimal length was $1.0 \mathrm{~mm}$, in majority cases the lengths of the foramen spinosum ranges between 2.0 to $2.5 \mathrm{~mm}$. The maximal width of foramen spinosum was $2.0 \mathrm{~mm}$ and the minimal width was $1.0 \mathrm{~mm}$, some of the foramen spinosum were partially divided into two components by bony spurs [19].

The same investigator also studied about the shape of foramen spinosum, the results were oval, circular and triangular, but not mentioned thepercentage, in our present study same shapes of foramen spinosum were observed. Yanagi observed that the earliest perfect ring shaped formation of the foramen spinosum was observed in the 8th month after birth and the latest in 7 years after birth in a developmental study on the foramen rotundum, foramen ovale and foramen spinosum, the majority of the foramen in the skulls studies was round in shape [20]. The present study provides essential information about variations in morphology and morphometry of foramen spinosum. The variations are of clinical significance in fractures of base of skull and in diagnosing any aneurysms or vascular lesions in cranial cavity. This knowledge very important for neurosurgeons to identify and preserve the neurovascular structures while approaching middle cranial fossa.

\section{Conflicts of Interests: None}

\section{REFERENCES}

[1]. Dogan, N. U., Fazhogullari, Z., Uysal, I. I., Seker, M . \& Karabulut. A. K. Anatomical examination of the foramens of the middle cranial fossa. Int. J. M orphol., 2014;32(1):43-8.

[2]. Curtin, H. D., Williams, R. \& Johnson, J. CT of perineural tumor extension: pterygopalatine fossa. AJNR Am. J. Roentgenol., 1985;144(1):163-9.

[3]. Pandolfo, I., Gaeta, M., Blandino, A. \& Longo, M. The radiology of the pterygoid canal: normal and pathologic findings. AJNR Am. J. Neuroradiol., 1987;8(3):479-83.

[4]. Kwathai, L., Namonta, K., Rungruang, T., Chaisuksunt, V., Apinhasmit, W. \& Chompoopong, S. Anatomic and morphometric consideration for external landmarks of foramen spinosum in thai dry skulls. Siriraj Med. J., 2012;64(Suppl. 1):S26-9.

[5]. Srimani, P., M ukherjee, P., Sarkar, M.; Roy, H., Sengupta, S. K., Sarkar, A. N. \& Ray, K. Foramina in alisphenoid - An observational study on their osseous-morphology and morphometry. Int. J. Anat. Radiol. Surg., 2014;3(1):1-6.

[6]. Karan BK, Surekha DJ, Umarji BN, Patil RJ, Ambali M P. Foramen ovale and foramen spinosum: a morphometric study. Anatomica Karnataka. 2012;6(3):68-72.

[7]. Rai AL, Gupta N, Rohatgi R. Anatomical variations of foramen spinosum. Innovative Journal of Medical and Health Science. 2012;2(5):86-8.

[8]. Khan AA, Asari M A, Hassan A. Anatomic variants of foramen ovale and spinosum in human skulls. Int J Morphol. 2012;30(2):445-9.

[9]. Krayenbuhl N, Isolan GR, Al-M efty 0 . The foramen spinosum: a landmark in middle fossa surgery. Neurosurg Rev. 2008;31(4):397-401.

[10]. Ustan ME, Buyukmumcu M, Ulku CH, Guney O, Salbacak A. Transzygomatic-subtemporal approach for middle meningeal artey-to-P2 segment of posterior cerebral artery bypass: an anatomical and technical study. Skull Base. 2006;16(1): 39-44. 
[11]. Lang J, Maier R, Scafhauser O. Postnatal enlargement of the foramina rotundum, ovale et spinosum and their topographical changes. Anat Anaz. 1984;156:351-87.

[12]. Shaik HS, Shepur MP, Desai SD, Thomas ST, Maavishettar GF, Haseena S. Study of mastoid canals and grooves in South Indian skulls. Indian J Med Healthc 2012;1:32-33.

[13]. Jeyanthi Krishnamurthy, Lalitha Chandra, Shubha Rajanna. Morphometric Study Of Foramen Spinosum In Humanskulls. Int J Cur Res Rev, July 2013;05(14):44-48.

[14]. L. Lazarus, N. Naidoo, Satyapal, K. S. An Osteometric Evaluation of the Foramen Spinosum and Venosum. Int. J. M orphol. 2015;33(2):452-458.

[15]. S.D Desai, Hussain S.S, M uralidhar S.P, Thomas S.T, M avishettar G.F, Haseena.S. M orphometric analysis of Foramen Spinosum in South Indian skulls. J.Pharm. Sci. \& Res 2012;4(12):2022-2024.

[16]. Lindblom K. A roentgenographic study of the vascular channels of the skull, with special reference to intracranial tumors and arteriovenous aneurysms. Acta Radiol Suppl. 1936;30:1-146.
[17]. Berlis A, Putz R, Schumacher M . Direct and CT measurements of canals and foramina of the skull base. Br J Radiol. 1992 Aug;65(776):653-61.

[18]. Wood-Jones F. The non-metrical morphological characters of the skull as criteria for racial diagnosis. par 1: General discussion of the morphological characters employed in racial diagnosis. J. Anat. 1931;65:179-495.

[19].Osunwoke EA, Mbadugha CC, Orish CN, Oghenemavwe EL, Ukah C]. A morphometric study of foramen ovale and foramen spinosum of the human sphenoid bone in the southern Nigerian population. J Appl Biosci. 2010 Feb;26:1631-5.

[20]. Yanagi S. Developmental studies on the foramen rotundum, foramen ovale and foramen spinosum of the human sphenoid bone. The Hokkaido Journal of Medical Science. 1987;62(3):485-96.

\author{
How to cite this article: \\ Shaik Hussain Saheb, Khaleel N, Pavan P Havaldar, Shruthi B.N \\ M ORPHOLOGICAL AND M ORPHOM ETRIC STUDY OF FORAM EN \\ SPINOSUM . Int J Anat Res 2017;5(4.1):4523-4526. DOI: 10.16965/ \\ ijar.2017.389
}

